\title{
Elevated folic acid results in contrasting cancer cell line growth with implications for mandatory folic acid fortification*
}

\author{
Yates, Zoe ${ }^{1} \cdot$ Lucock, Mark ${ }^{2} \cdot$ Veysey, Martin ${ }^{3} \cdot$ Choi, Jeong-hwa ${ }^{2 \dagger}$ \\ ${ }^{1}$ School of Biomedical Sciences and Pharmacy, University of Newcastle, Ourimbah NSW 2258, Australia \\ ${ }^{2}$ School of Environmental \& Life Sciences, University of Newcastle, Ourimbah NSW 2258, Australia \\ ${ }^{3}$ Teaching \& Research Unit, Central Coast Local Health District, Gosford NSW 2250, Australia
}

\begin{abstract}
Purpose: The initiation of mandatory folic acid fortification using pteroylmonoglutamic acid (PteGlu) has reduced the rate of congenital malformations. However, it also appears to be responsible for several adverse effects, including increased cancer incidence. This may be related to physicho-chemical characteristics of PteGlu. This study examines the potential effect of high concentrations of PteGlu on a population subjected to mandatory folic acid fortification using an in vitro model. Methods: Caco-2 (colorectal cancer) and MCF7 (breast cancer) cell lines were cultured at 6 different PteGlu concentrations $(0,0.1,1,50,250$, and $500 \mu \mathrm{g} / \mathrm{ml})$ for 6 days. Cell growth was determined using thiazolyl blue tetrazolium bromide assay. The genotype of dihydrofolate reductase 19bp deletion/insertion (DHFR 19-del) was also scored in cell lines using a restriction fragment length polymorphism technique to examine whether genetic variations may factor in cell proliferation. Results: PteGlu exhibited differential growth promoting properties between cell lines. Caco-2 cells did not show a significant growth difference at low concentrations compared to control, however, at higher concentrations, the growth showed a contrasting trend in the early experimental period, while MCF7 showed enhanced cell growth at all concentrations. The DHFR 19-del genotype differed in the two cell lines. Conclusions: Altered response to PteGlu by Caco-2 and MCF7 may reflect a tissue specific disease aetiology or genotype specific differential enzyme activity, for example by DHFR, to critical levels of PteGlu. As folic acid fortification is a blanket intervention, and DHFR and other enzyme activities vary between individuals, PteGlu intake may have an as yet undefined effect on health. These findings may be relevant when considering mandatory folic acid fortification for disease prevention.
\end{abstract}

KEY WORDS: folate, Caco-2, MCF7, DHFR, folic acid fortification

\section{INTRODUCTION}

Folate plays an essential role as a major coenzyme in onecarbon metabolism. It has been suggested that inappropriate folate nutritional status can result in carcinogenesis via aberrant DNA methylation. This process arises because of decreased S-adenosylmethionine (SAM) synthesis and hence an alteration in gene expression. Folate shortage can also impair DNA stability via misincorporation of uridylate into DNA. ${ }^{1}$ As part of the molecular process of carcinogenesis, folate deficiency in normal tissue may predispose cells to neoplastic transformation ${ }^{2,3}$ or suppress the progression of pre-existing neoplasms in model systems. ${ }^{2,4-6}$ By contrast, recent research has found that high folate levels may actually increase cancer incidence. ${ }^{7,8}$ These intriguing, yet contradictory findings relating to the development and progression of cancer imply that a defined and moderate level of folate intake and blood status is critical to maintaining health. ${ }^{9}$

Studies now suggest that folate intake and blood folate level are related to cancer risk particularly of colon and breast cancer. ${ }^{1,10,11}$ Large studies indicate folate plays a role as a major aetiological factor in colorectal cancer risk with high folate intake reducing colorectal risk by about $40 \%$ compared to low folate intake, although results are inconsistent. For instance, low folate level was reported to have a protective effect against colorectal cancer, ${ }^{7}$ while high dose folic acid supplements might increase the risk of colorectal neoplasia. ${ }^{10,12}$ Folate has also been considered as one of the factors involved in breast cancer aetiology.

Received: March 20, 2016 / Revised: April 11, 2016 / Accepted: April 14, 2016

*This work was supported by grants from Ramaciotti Foundation and Northern Sydney Local Health District, NSW, Australia.

${ }^{\dagger}$ To whom correspondence should be addressed.

Tel: +82-10-8603 9054, e-mail: 73805@ncc.re.kr (Jeong-hwa Choi) 
Recent studies suggest that folate has a protective effect against breast cancer, ${ }^{13,14}$ with high concentrations of homocysteine and cysteine affording greater risk for breast cancer when folate levels were low. ${ }^{15}$ However, a number of studies reported conflicting results such as no relationship between folate intake or blood folate levels and breast cancer risk, ${ }^{16}$ or that high folate intake may increase the risk of breast cancer. ${ }^{8,17}$ To date, there is no clear explanation for this conflicting role of folate status on cancer risk.

Since the commencement of mandatory folic acid fortification with pteroylmonoglutamic acid (PteGlu) in several countries from the late 1990s, the blood folate status of many populations has been enhanced. ${ }^{18}$ As a consequence of this, there has been a striking reduction in congenital malformation rates including neural tube defects. ${ }^{19}$ Despite this major public health achievement, emerging evidence shows that mandatory folic acid fortification and elevated folate level might be responsible for several adverse effects, including the accumulation of unmetabolized PteGlu in blood, a changed distribution of cellular folyl vitamers, ${ }^{20}$ reduced natural killer cell cytotoxicity, ${ }^{21}$ a rise in twin births ${ }^{22}$ and the mean dose for methotrexate therapy. ${ }^{23}$ It has also been speculated that the increase of colorectal cancer incidence since mandatory folic acid fortification may be due to the higher folate intake, or exposure to altered folyl vitamers. ${ }^{10,24-26}$ For many of these phenomena we do not have any clear explanation. However, folic acid fortification using PteGlu as a main vehicle does seem to elicit an effect on health.

Therefore, we examined the effects of various experimental concentrations of PteGlu on the growth of colorectal (Caco-2) and breast cancer (MCF7) cell lines to explore the potential effects that PteGlu might have on health outcomes including carcinogenesis. The genotype of a common variant in a key protein involved in PteGlu metabolism; dihydrofolate reductase 19bp deletion/insertion (DHFR 19-del), was also determined in the two cell lines. We were particularly interested to elucidate findings in the context of population level mandatory folic acid fortification.

\section{MATERIALS AND METHODS}

\section{Chemicals and Reagents}

The following chemicals for cell culture and cell growth measurement were purchased from Sigma (CA, USA): Rosewell Park Memorial Institute medium 1640 (RPMI
1640), folate free RPMI 1640, L-glutamine, foetal bovine serum (FBS), phosphate buffered saline, EDTA-trypsin solution, thiazolyl blue tetrazolium bromide (MTT) and dimethyl sulfoxide. PteGlu was purchased from Schircks laboratories (Jona, Switzerland). For genotype scoring of DHFR 19-del variant, DNA was extracted using QIAamp DNA blood mini kit purchased from Qiagen (Hilden, Germany), for DNA amplification. Oligonucleotides were synthesized by Invitrogen (CA, USA). Other chemicals for genotyping determination including restriction enzymes were purchased from Promega (WI, USA). Reagents for electrophoresis (agarose and tris-borate EDTA buffer) were purchased from Sigma (CA, USA).

\section{Preparation of Cell Lines}

The human colon cancer cell line Caco-2, and breast cancer cell line MCF7 were purchased from the European Collection of Cell Cultures (Salisbury, UK). Cells were initially cultured in normal RPMI 1640 medium containing $10 \%$ FBS. For adjusting cells to folate free medium, cells were cultured in media, slowly changing the ratio of folate free and standard RPMI 1640 for three weeks. Folate free medium contains only a small amount of folate derived from FBS $(\sim 1 \mathrm{ng} / \mathrm{ml})$, this level of folate in the growth medium is able to maintain growth of cell lines at a physiologically sustainable level. ${ }^{27}$ The medium was changed every other day, and cell lines were passaged every four days. Cell lines were incubated at $37^{\circ} \mathrm{C}$ in $95 \%$ humidity and $5 \% \mathrm{CO}_{2}$.

\section{Cell culture}

Caco-2 and MCF7 cells pre-cultured in folate free medium were seeded at a density of $3 \times 10^{3}$ cell/well in 24well plate. These cells were cultured in the media with 5 concentrations of PteGlu, as well as a control $(0 \mu \mathrm{g} / \mathrm{ml})$, for 6 days: relatively low concentration (at and below the level of normal RPMI 1640) $-0.1 \mu \mathrm{g} / \mathrm{ml}$ and $1 \mu \mathrm{g} / \mathrm{ml}$, and high concentration - $50 \mu \mathrm{g} / \mathrm{ml}, 250 \mu \mathrm{g} / \mathrm{ml}$ and $500 \mu \mathrm{g} / \mathrm{ml}$. The $\mathrm{pH}$ value of the PteGlu standard was 6.5.

\section{Cell Growth determination}

Cell growth was determined using modified MTT assay according to Alley et al. ${ }^{28}$ The cell growth of each plate was read on day 2, 4 and 6 using a microplate reader (Benchmark plus, Bio-Rad, CA, USA). All experiments were done in triplicate. Cell growth change was calculated 
using the average absorbance of three wells for each concentration, and presented as percentage growth compared to the water control. To examine the variation between each test, the coefficient of variation was calculated, which was below $10 \%$ in all cases.

\section{Genotyping for the DHFR polymorphism}

Genomic DNA from Caco-2 and MCF7 cells was extracted, and DHFR 19-del genotype ascertained according to Johnson et al.. ${ }^{29}$

\section{Statistical analysis}

All statistical analysis was performed using SPSS 13.0 for windows (SAS, IL, USA). Student's t-test, ANOVA and Fisher's least significant difference post hoc test was performed to compare the cell growth with a $95 \%$ confidence level.

\section{RESULTS}

\section{DHFR 19-del genotype}

The Caco-2 and MCF7 cell lines have a different DHFR 19-del genotype. The Caco-2 cell line was homozygous recessive with two deletion alleles, but the MCF7 cell line was heterozygous, reflecting carriage of both the deletion and non-deletion allele.

\section{Caco-2 cell growth}

Figure 1 shows the effect of PteGlu on Caco-2 cell growth. PteGlu resulted in a differential response in Caco-2 cells at each concentration. At $0.1 \mu \mathrm{g} / \mathrm{ml}$ and $1 \mu \mathrm{g} / \mathrm{ml}$ PteGlu, there were only minor and non-significant growth differences compared to the control. The cells were also cultured in lower PteGlu concentrations $-1 \mathrm{ng} / \mathrm{ml}$ and 10 $\mathrm{ng} / \mathrm{ml}$ but again cells did not show any significant difference (data not shown). This may be due to the high baseline levels of PteGlu in the normal RPMI 1640 initially used to culture the cells $(1 \mu \mathrm{g} / \mathrm{ml})$. However, Caco- 2 cells exhibited significant differences in growth at higher PteGlu concentrations. $50 \mu \mathrm{g} / \mathrm{ml}$ PteGlu enhanced Caco-2 cell growth, peaking on day 4 being enhanced by $36 \%(p=0.008)$. By contrast, Caco-2 growth was suppressed by $250 \mu \mathrm{g} / \mathrm{ml}$ and $500 \mu \mathrm{g} / \mathrm{ml}$ on day 2 and 4 . With concentration of $500 \mu \mathrm{g} / \mathrm{ml}$, cell growth was inhibited by approximately $30 \%$ on day 2 $(\mathrm{p}=0.005)$ but this inhibition was reversed by day 4 . All concentrations promoted Caco-2 cell growth by day 6 , but in all cases this was not statistically significant.

\section{MCF7 growth}

PteGlu conferred a different growth pattern in MCF7

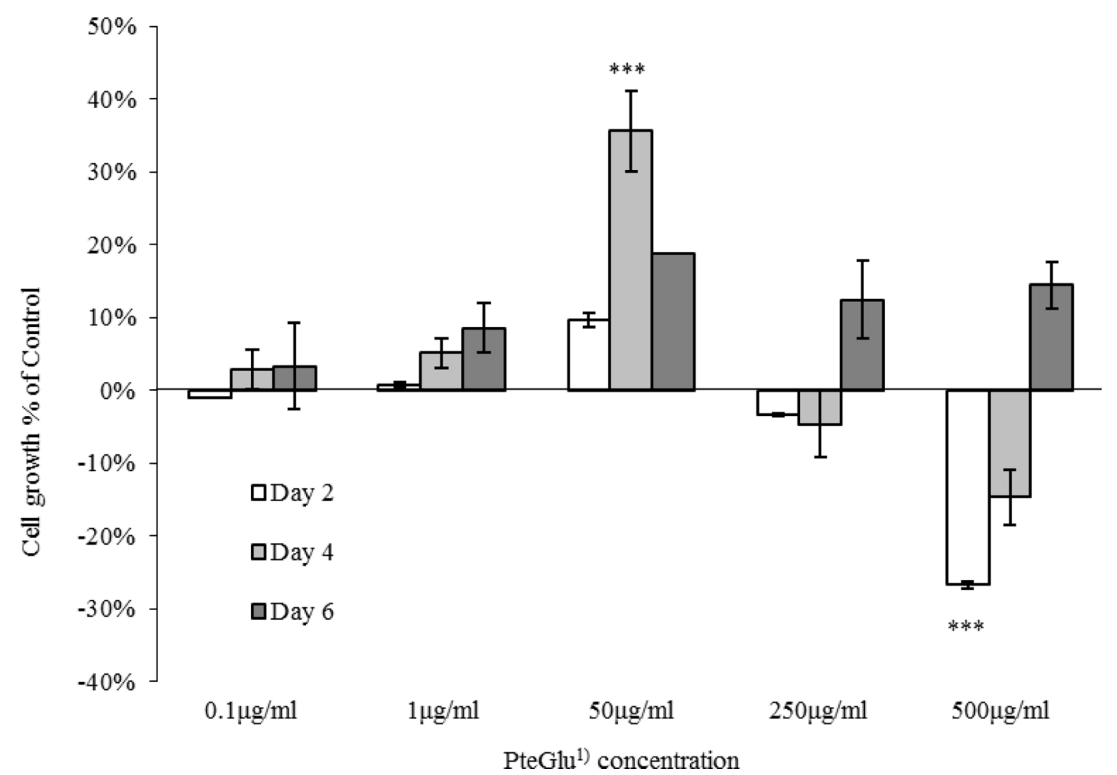

Fig. 1. Effects of PteGlu on growth of colon cancer cell line (Caco-2) for 6 days. Caco-2 cells were seeded at a density of $3 \times 10^{3} /$ well and were cultured in medium with the presence of 5 different PteGlu concentrations, including a control $(0 \mu \mathrm{g} / \mathrm{ml})$. Cell growth was determined on day 2,4 and 6 , using thiazolyl blue tetrazolium bromide assay, and was presented as a percent of control. Each bar expresses the mean \pm SD from triplicate analyses. Asterisks present the significant differences compared to the control group as determined by ANOVA with a confidence level of $95 \%\left({ }^{* * *} p=0.008\right.$ and $\left.{ }^{* * *} p=0.005\right)$. 1) PteGlu: pteroylmonoglutamic acid 


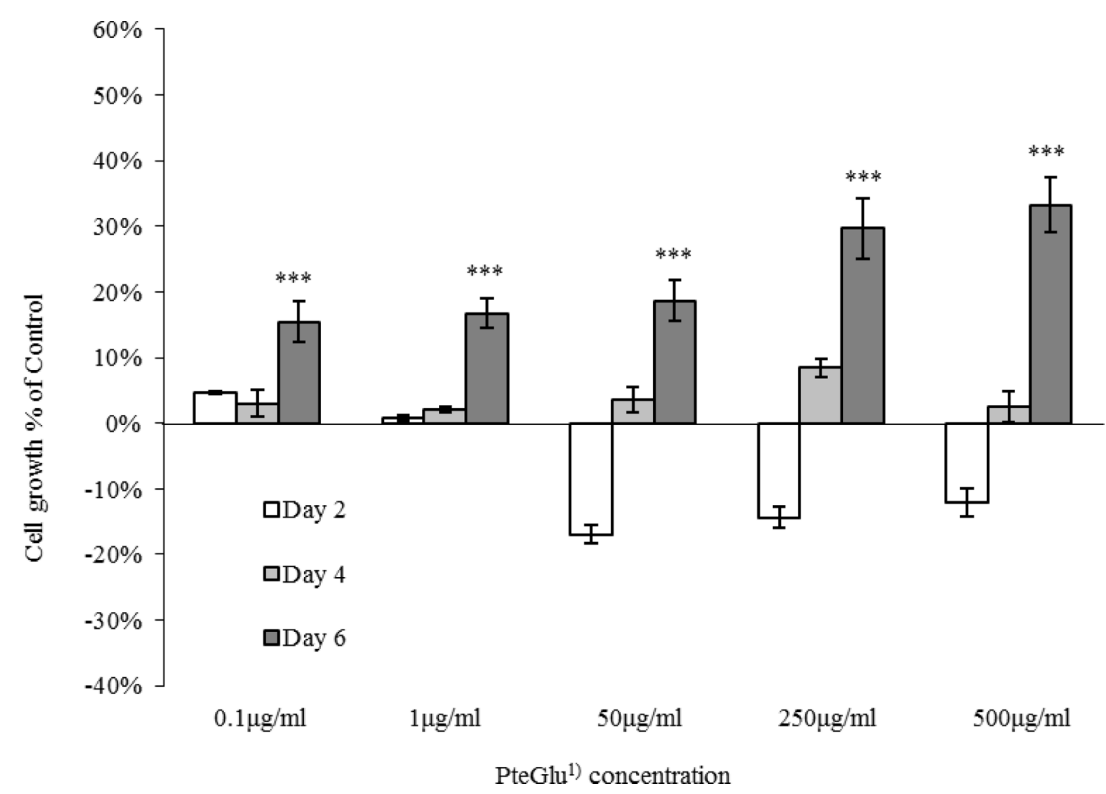

Fig. 2. Effects of PteGlu on growth of breast cancer cell line (MCF7) for 6 days. MCF7 cells were seeded at a density of $3 \times 10^{3} /$ well and were cultured in medium with the presence of 5 different PteGlu concentrations, including a control $(0 \mu \mathrm{g} / \mathrm{ml})$. Cell growth was determined on day 2, 4 and 6, using thiazolyl blue tetrazolium bromide assay, and was presented as a percent of control. Each bar expresses the mean \pm SD from triplicate analyses. Asterisks present the significant differences compared to the control group as determined by ANOVA with a confidence level of $95 \%(* * *<0.0001)$. 1) PteGlu: pteroylmonoglutamic acid

cells in response to PteGlu concentrations compared to Caco-2 cells (Fig. 2). Although it was not statistically significant, on day 2, cell growth was increased at concentrations of $0.1 \mu \mathrm{g} / \mathrm{ml}$ and $1 \mu \mathrm{g} / \mathrm{ml}$. The remaining three higher concentrations of PteGlu $(50 \mu \mathrm{g} / \mathrm{ml}, 250 \mu \mathrm{g} / \mathrm{ml}$ and $500 \mu \mathrm{g} / \mathrm{ml}$ ) inhibited MCF7 cell growth by an inverse proportion on day 2. Interestingly, $50 \mu \mathrm{g} / \mathrm{ml}$ of PteGlu increased cell growth of Caco-2 cells on day 2, however it caused contrasting cell growth inhibition with MCF7 on the same day. This MCF7 growth inhibition with above 50 $\mu \mathrm{g} / \mathrm{ml}$ PteGlu was no longer apparent on day 4 . All PteGlu concentrations significantly increased growth of MCF7 cells compared to the control on day $6(p<0.0001)$, yet this noticeable cell growth was not observed in the Caco-2 cell line. This MCF7 cell growth with each PteGlu concentration did not differ within groups, however it did occur in a dose dependant manner with $500 \mu \mathrm{g} / \mathrm{ml}$ enhancing cell growth up to $33 \%$ (p $<0.0001)$.

\section{DISCUSSION}

Folate is one of the best studied nutrients in relation to human health and has been extensively researched since the discovery that it can prevent $\mathrm{NTD}^{30,31}$ and reduce homocysteine. ${ }^{18,32}$ However, emerging evidence suggests that folate is also a significant nutrient in oncogenesis. Inappropriate folate intake and status are key risk factors for cancer due to the vitamin's critical role in DNA methylation and synthesis. Low folate nutrition is known to be associated with increased risk for cancer via aberrant DNA methylation and impaired stability. On the other hand, excess folate could also be a concern, which may prompt the progression of pre-existing neoplasms via alteration in purine and/or pyrimidine synthesis. ${ }^{9}$ The effect of folate on health, as a consequence, has been described as a double-edged sword. ${ }^{9}$ Timing and doses are therefore critical in using folic acid while treating cancer. ${ }^{33}$

The current study investigated the effects of PteGlu concentrations on the growth of both colon and breast cancer cell lines. Each cancer cell line was grown in media with different PteGlu concentrations for 6 days. At relatively low concentrations $(0.1 \mu \mathrm{g} / \mathrm{mL}$ and $1 \mu \mathrm{g} / \mathrm{mL})$, there was no significant difference of Caco-2 cell growth compared to the control. Even though Caco-2 cells had an adaption period to folate free medium for 3 weeks prior to the main experiment, high levels of baseline PteGlu within the culture medium may have resulted in a 'threshold effect' for the Caco-2 cells in relation to PteGlu metabolism. Therefore, this may explain why no significant change of cell growth was observed with a comparatively low PteGlu 
level.

Interestingly, Caco-2 cells showed significantly different growth patterns at high concentrations $-50 \mu \mathrm{g} / \mathrm{ml}$ and 500 $\mu \mathrm{g} / \mathrm{ml}$ of PteGlu. Caco-2 cell growth was enhanced, peaking on day 4 at $50 \mu \mathrm{g} / \mathrm{ml}$. At a PteGlu concentration of $500 \mu \mathrm{g} /$ $\mathrm{ml}$, however, Caco-2 growth was suppressed significantly on day 2 ( $p<0.005)$, this suppression effect was no longer apparent on day 6. It may be hypothesized that the effect of high PteGlu concentration is related to PteGlu metabolism which differs from the metabolism of natural folate coenzymes (Fig. 3).

PteGlu is a synthetic form of folate which does not exist naturally and needs an additional step to enter into human folate metabolism. This additional step is via DHFR. DHFR mainly catalyzes the reduction of dihydrofolate $\left(\mathrm{H}_{2} \mathrm{PteGlu}\right)$ to tetrahydrofolate $\left(\mathrm{H}_{4} \mathrm{PteGlu}\right)$. It is also responsible for conversion of PteGlu to $\mathrm{H}_{2}$ PteGlu but with a very high $K_{\mathrm{m}}$ (Fig. 4). In addition, $\mathrm{H}_{2}$ PteGlu allosterically modulates activity of methylentetrahydrofolate reductase (MTHFR), the central enzyme of folate metabolism. ${ }^{34}$ PteGlu from fortified food and supplements is turned into $\mathrm{H}_{2}$ PteGlu and is metabolized into $\mathrm{H}_{4}$ PteGlu by DHFR. Considering these characteristics of folate metabolism, the increased growth of Caco-2 cells at $50 \mu \mathrm{g} / \mathrm{ml}$ PteGlu could possibly be explained as follows: $\mathrm{H}_{2}$ PteGlu inhibits MTHFR activity sparing 5,10-methylenetetrahydrofolate, which is shunted towards purine and pyrimidine biosynthesis instead of the methylation process. In this way PteGlu promotes cell proliferation, and therefore Caco-2 cells in $50 \mathrm{ug} / \mathrm{ml}$ may show dominant growth compared to control cells (Fig. 3). ${ }^{34}$

The high $K_{\mathrm{m}}$ of PteGlu for DHFR has also led to the idea that PteGlu may be an antimetabolite for DHFR, conferring competitive substrate inhibition on DHFR's activity towards $\mathrm{H}_{2}$ PteGlu (Fig. 4). ${ }^{35}$ In the context of this substrate inhibition, $500 \mu \mathrm{g} / \mathrm{ml}$ may be a critical concentration that could result in a decrease of DHFR activity, thereby reducing $\mathrm{H}_{2}$ PteGlu product formation and leading to the presence of less $\mathrm{H}_{4}$ PteGlu to act as a thymidilate precursor for DNA synthesis. This mechanism might theoretically lead to a decrease in cell growth. ${ }^{36}$

MCF7 breast cancer cells showed a different response pattern from Caco-2 cells. MCF7 cells exhibited only a

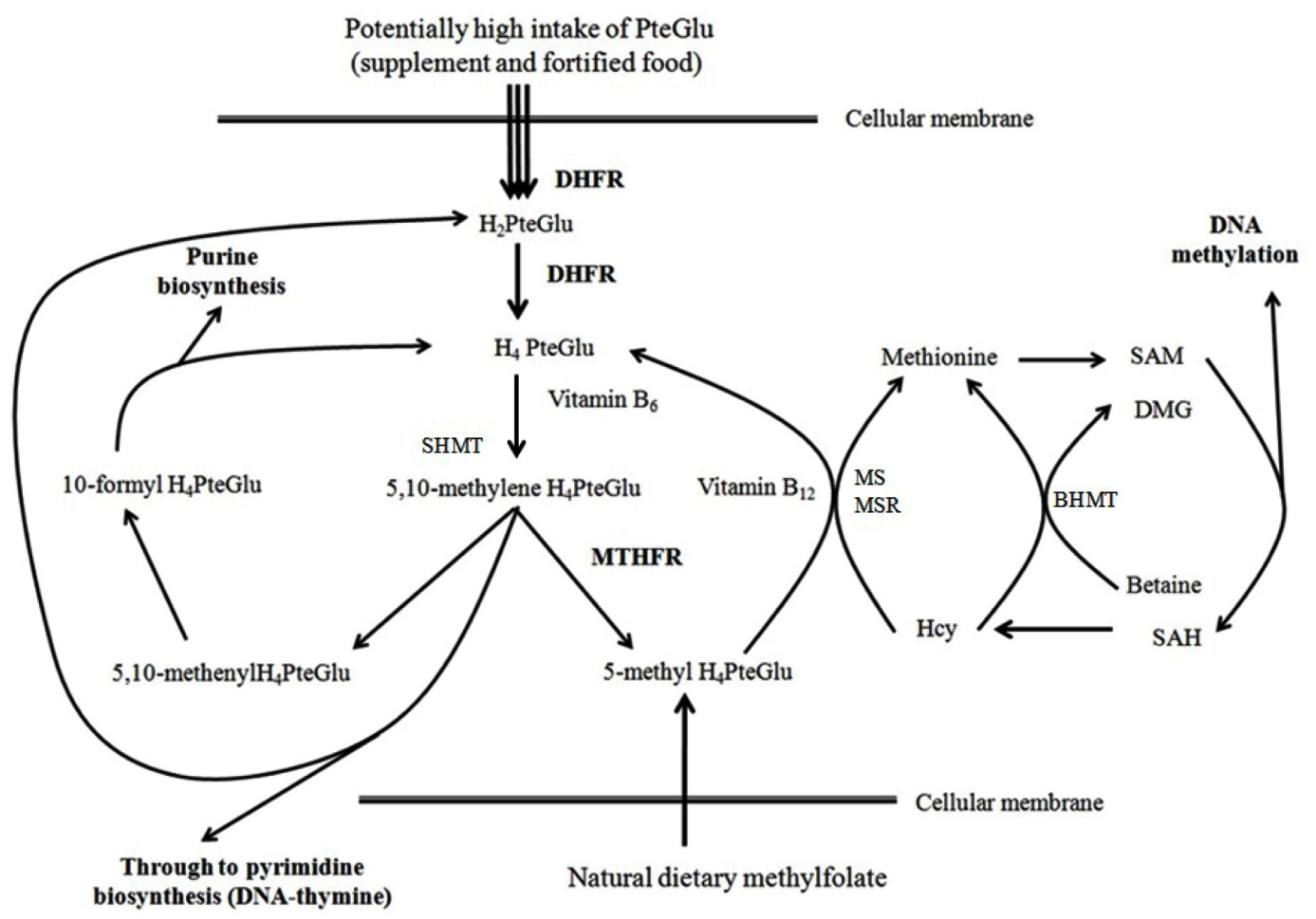

Fig. 3. Scheme for folate metabolism showing utilisation of PteGlu and flux of one carbon units between DNA synthesis and methylation. Abbreviations: DHFR, dihydrofolate reductase; $\mathrm{H}_{2}$ PteGlu, dihydrofolate; $\mathrm{H}_{4}$ PteGlu, tetrahydrofolate; SHMT, serine hydroxymethyltransferase; MTHFR, methylentetrahydrofolate reductase; MS, methionine synthase; MSR, methyionine synthase reductase; BHMT, betainehomocysteine methyltransferase; Hcy, homocysteine; DMG, dymethylglycine; SAM, S-adenosylmethionine; SAH, S-adenosylhomocysteine 


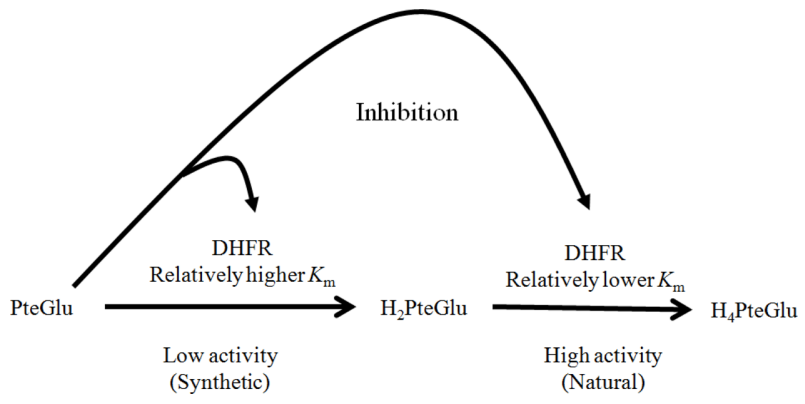

Fig. 4. Reaction diagram for PteGlu and dihydrofolate reductase. Abbreviations: DHFR, dihydrofolate reductase; $\mathrm{H}_{2}$ PteGlu, dihydrofolate; $\mathrm{H}_{4}$ PteGlu, tetrahydrofolate

minor growth difference on day 2 and 4 , yet all concentrations showed significantly increased growth when compared to the control on day $6(\mathrm{p}<0.0001)$. It is possible to speculate that the DHFR enzyme activity of MCF7 is different from that of Caco-2 and, as a result MCF7 responded to PteGlu with a different pattern of growth. Such a discrepancy for DHFR activity has been reported previously. ${ }^{35,37}$ DHFR activity varies between species, with the activity of DHFR in the rat being higher than in humans. Furthermore, approximately 5-fold differences in DHFR activity between individuals have been reported. ${ }^{35}$ DHFR also has various inhibition levels depending on the type of antifolate present. ${ }^{37}$ Additionally, the ratio of $\mathrm{H}_{2}$ PteGlu/PteGlu and presence of genetic variants in DHFR could possibly affect enzyme activity. ${ }^{29,38,39}$ The Caco-2 and MCF7 cell lines used for this study were confirmed as having different DHFR 19-del genotypes. It has already been reported that the DHFR 19-del homozygous recessive genotype exhibits altered DHFR mRNA expression compared to the heterozygous genotype. ${ }^{29,40}$ In terms of DHFR activity, these findings could explain the differential cell growth response found between the two cell lines, raising questions related to the catalytic effect of PteGlu on DHFR in the context of subject, tissue and genotype.

In terms of mandatory folic acid fortification, the differential response of each cancer cell line may possibly imply other adverse effects of the fortification programme: Especially when considering the above results and difference in enzyme activities between individuals. Although it was mainly intended to target women of child-bearing age, the implementation of mandatory folic acid fortification has increased the total dietary folate intake of the entire population as a blanket intervention. The level of mandatory fortification has been adjusted for each country, taking into account nutritional intake status of its population and disease risk. However, the diverse characteristics of the population which could alter disease risk such as the presence of undiagnosed diseases, prescribed medications, supplement intake and genetic characteristics were not considered. ${ }^{41}$ In addition, the chronic exposure to excess PteGlu may lead to a range of unexpected effects. Junaid et al. have reported that in lymphoblastoid cells, high PteGlu in culture medium caused dysregulation of expression in more than 1,000 genes. ${ }^{42}$ We speculate that the DHFRPteGlu interaction could be relevant: Excess PteGlu may effect DHFR activity, and its response may be differential, depending on genotype or individual, as observed in two different cell lines in the present study. In particular, excess PteGlu may have an influence on the progression of undiagnosed malignancies and potentially result in interactions with anti-cancer medicines, ${ }^{43}$ as DHFR is a major target for multiple antifolate drugs. ${ }^{44}$ Therefore, further research with respect to the safety and efficacy of mandatory folate fortification, taking these factors into account, is required.

The findings of current study however are required to be interpreted with caution. The effect of PteGlu on cell proliferation was only determined by alteration of growth rate compared to control. Additionally, such differential growth trends may mainly present the tissue or disease specific characteristics in in vitro culture system.

\section{CONCLUSION}

Present data suggests that long-term exposure to high concentration PteGlu may potentially have a baseline effect in colon cancer cells, and that elevated PteGlu can lead to a contrast in the growth pattern of two different cancer cell lines, with the effect depending on exposure time and level of PteGlu, type of cancer and tissue. These findings are likely to be relevant when considering folic acid fortification in disease prevention.

\section{REFERENCES}

1. Prinz-Langenohl R, Fohr I, Pietrzik K. Beneficial role for folate in the prevention of colorectal and breast cancer. Eur J Nutr 2001; 40(3): 98-105.

2. Kim YI. Folate and colorectal cancer: an evidence-based critical review. Mol Nutr Food Res 2007; 51(3): 267-292.

3. Kim YI. Role of folate in colon cancer development and progression. J Nutr 2003; 133(11 Suppl 1): 3731S-3739S. 
78 / Folic acid levels and cancer cell line growth

4. Kim YI. Folate and carcinogenesis: evidence, mechanisms, and implications. J Nutr Biochem 1999; 10(2): 66-88.

5. Choi SW, Mason JB. Folate status: effects on pathways of colorectal carcinogenesis. J Nutr 2002; 132(8 Suppl): 2413S-2418S.

6. Bills ND, Hinrichs SH, Morgan R, Clifford AJ. Delayed tumor onset in transgenic mice fed a low-folate diet. J Natl Cancer Inst 1992; 84(5): 332-337.

7. Van Guelpen B, Hultdin J, Johansson I, Hallmans G, Stenling R, Riboli E, Winkvist A, Palmqvist R. Low folate levels may protect against colorectal cancer. Gut 2006; 55(10): 1461-1466.

8. Stolzenberg-Solomon RZ, Chang SC, Leitzmann MF, Johnson KA, Johnson C, Buys SS, Hoover RN, Ziegler RG. Folate intake, alcohol use, and postmenopausal breast cancer risk in the Prostate, Lung, Colorectal, and Ovarian Cancer Screening Trial. Am J Clin Nutr 2006; 83(4): 895-904.

9. Lucock M, Yates Z. Folic acid fortification: a double-edged sword. Curr Opin Clin Nutr Metab Care 2009; 12(6): 555-564.

10. Cole BF, Baron JA, Sandler RS, Haile RW, Ahnen DJ, Bresalier RS, McKeown-Eyssen G, Summers RW, Rothstein RI, Burke CA, Snover DC, Church TR, Allen JI, Robertson DJ, Beck GJ, Bond JH, Byers T, Mandel JS, Mott LA, Pearson LH, Barry EL, Rees JR, Marcon N, Saibil F, Ueland PM, Greenberg ER; Polyp Prevention Study Group. Folic acid for the prevention of colorectal adenomas: a randomized clinical trial. JAMA 2007; 297(21): 2351-2359.

11. Baggott JE, Morgan SL. Folic acid supplements are good (not bad) for rheumatoid arthritis patients treated with low-dose methotrexate. Am J Clin Nutr 2008; 88(2): 479-480.

12. Ebbing M, Bønaa KH, Nygård $\mathrm{O}$, Arnesen E, Ueland PM, Nordrehaug JE, Rasmussen K, Njølstad I, Refsum H, Nilsen DW, Tverdal A, Meyer K, Vollset SE. Cancer incidence and mortality after treatment with folic acid and vitamin B12. JAMA 2009; 302(19): 21192126.

13. Lajous M, Romieu I, Sabia S, Boutron-Ruault MC, ClavelChapelon F. Folate, vitamin B12 and postmenopausal breast cancer in a prospective study of French women. Cancer Causes Control 2006; 17(9): 1209-1213.

14. Ericson U, Sonestedt E, Gullberg B, Olsson H, Wirfält E. High folate intake is associated with lower breast cancer incidence in postmenopausal women in the Malmö Diet and Cancer cohort. Am J Clin Nutr 2007; 86(2): 434-443.

15. Lin J, Lee IM, Song Y, Cook NR, Selhub J, Manson JE, Buring JE, Zhang SM. Plasma homocysteine and cysteine and risk of breast cancer in women. Cancer Res 2010; 70(6): 2397-2405.

16. Larsson SC, Giovannucci E, Wolk A. Folate and risk of breast cancer: a meta-analysis. J Natl Cancer Inst 2007; 99(1): 64-76.

17. Stevens VL, McCullough ML, Sun J, Gapstur SM. Folate and other one-carbon metabolism-related nutrients and risk of postmenopausal breast cancer in the Cancer Prevention Study II Nutrition Cohort. Am J Clin Nutr 2010; 91(6): 1708-1715.

18. Pfeiffer CM, Caudill SP, Gunter EW, Osterloh J, Sampson EJ. Biochemical indicators of B vitamin status in the US population after folic acid fortification: results from the National Health and Nutrition Examination Survey 1999-2000. Am J Clin Nutr 2005; 82(2): 442-450.

19. Honein MA, Paulozzi LJ, Mathews TJ, Erickson JD, Wong LY. Impact of folic acid fortification of the US food supply on the occurrence of neural tube defects. JAMA 2001; 285(23): 2981-
2986.

20. Kalmbach RD, Choumenkovitch SF, Troen AM, D'Agostino R, Jacques PF, Selhub J. Circulating folic acid in plasma: relation to folic acid fortification. Am J Clin Nutr 2008; 88(3): 763-768.

21. Troen AM, Mitchell B, Sorensen B, Wener MH, Johnston A, Wood B, Selhub J, McTiernan A, Yasui Y, Oral E, Potter JD, Ulrich CM. Unmetabolized folic acid in plasma is associated with reduced natural killer cell cytotoxicity among postmenopausal women. J Nutr 2006; 136(1): 189-194.

22. Waller DK, Tita AT, Annegers JF. Rates of twinning before and after fortification of foods in the US with folic acid, Texas, 1996 to 1998. Paediatr Perinat Epidemiol 2003; 17(4): 378-383.

23. Arabelovic S, Sam G, Dallal GE, Jacques PF, Selhub J, Rosenberg IH, Roubenoff R. Preliminary evidence shows that folic acid fortification of the food supply is associated with higher methotrexate dosing in patients with rheumatoid arthritis. J Am Coll Nutr 2007; 26(5): 453-455.

24. Hirsch S, Sanchez H, Albala C, de la Maza MP, Barrera G, Leiva L, Bunout D. Colon cancer in Chile before and after the start of the flour fortification program with folic acid. Eur J Gastroenterol Hepatol 2009; 21(4): 436-439.

25. Mason JB, Dickstein A, Jacques PF, Haggarty P, Selhub J, Dallal G, Rosenberg IH. A temporal association between folic acid fortification and an increase in colorectal cancer rates may be illuminating important biological principles: a hypothesis. Cancer Epidemiol Biomarkers Prev 2007; 16(7): 1325-1329.

26. Lucock M, Ng X, Boyd L, Skinner V, Wai R, Tang S, Naylor C, Yates Z, Choi JH, Roach P, Veysey M. TAS2R38 bitter taste genetics, dietary vitamin C, and both natural and synthetic dietary folic acid predict folate status, a key micronutrient in the pathoaetiology of adenomatous polyps. Food Funct 2011; 2(8): 457-465.

27. Novakovic P, Stempak JM, Sohn KJ, Kim YI. Effects of folate deficiency on gene expression in the apoptosis and cancer pathways in colon cancer cells. Carcinogenesis 2006; 27(5): 916-924.

28. Alley MC, Scudiero DA, Monks A, Hursey ML, Czerwinski MJ, Fine DL, Abbott BJ, Mayo JG, Shoemaker RH, Boyd MR. Feasibility of drug screening with panels of human tumor cell lines using a microculture tetrazolium assay. Cancer Res 1988; 48(3): 589-601.

29. Johnson WG, Stenroos ES, Spychala JR, Chatkupt S, Ming SX, Buyske S. New 19 bp deletion polymorphism in intron-1 of dihydrofolate reductase (DHFR): a risk factor for spina bifida acting in mothers during pregnancy? Am J Med Genet A 2004; 124A(4): 339-345.

30. Prevention of neural tube defects: results of the Medical Research Council Vitamin Study. Lancet 1991; 338(8760): 131-137.

31. Berry RJ, Li Z, Erickson JD, Li S, Moore CA, Wang H, Mulinare J, Zhao P, Wong LY, Gindler J, Hong SX, Correa A; China-U.S. Collaborative Project for Neural Tube Defect Prevention. Prevention of neural-tube defects with folic acid in China. N Engl J Med 1999; 341(20): 1485-1490.

32. Yang QH, Botto LD, Gallagher M, Friedman JM, Sanders CL, Koontz D, Nikolova S, Erickson JD, Steinberg K. Prevalence and effects of gene-gene and gene-nutrient interactions on serum folate and serum total homocysteine concentrations in the United States: findings from the third National Health and Nutrition Examination Survey DNA Bank. Am J Clin Nutr 2008; 88(1): 232-246. 
33. Smith AD, Kim YI, Refsum H. Is folic acid good for everyone? Am J Clin Nutr 2008; 87(3): 517-533.

34. Matthews RG, Haywood BJ. Inhibition of pig liver methylenetetrahydrofolate reductase by dihydrofolate: some mechanistic and regulatory implications. Biochemistry 1979; 18(22): 4845-4851.

35. Bailey SW, Ayling JE. The extremely slow and variable activity of dihydrofolate reductase in human liver and its implications for high folic acid intake. Proc Natl Acad Sci U S A 2009; 106(36): 15424-15429.

36. Chen MJ, Shimada T, Moulton AD, Cline A, Humphries RK, Maizel J, Nienhuis AW. The functional human dihydrofolate reductase gene. J Biol Chem 1984; 259(6): 3933-3943.

37. Albrecht AM, Biedler JL, Hutchison DJ. Two different species of dihydrofolate reductase in mammalian cells differentially resistant to amethopterin and methasquin. Cancer Res 1972; 32(7): 15391546.

38. Goto Y, Yue L, Yokoi A, Nishimura R, Uehara T, Koizumi S, Saikawa Y. A novel single-nucleotide polymorphism in the 3'untranslated region of the human dihydrofolate reductase gene with enhanced expression. Clin Cancer Res 2001; 7(7): 19521956.

39. Parle-McDermott A, Pangilinan F, Mills JL, Kirke PN, Gibney
ER, Troendle J, O'Leary VB, Molloy AM, Conley M, Scott JM, Brody LC. The 19-bp deletion polymorphism in intron-1 of dihydrofolate reductase (DHFR) may decrease rather than increase risk for spina bifida in the Irish population. Am J Med Genet A 2007; 143A(11): 1174-1180.

40. Xu X, Gammon MD, Wetmur JG, Rao M, Gaudet MM, Teitelbaum SL, Britton JA, Neugut AI, Santella RM, Chen J. A functional 19-base pair deletion polymorphism of dihydrofolate reductase (DHFR) and risk of breast cancer in multivitamin users. Am J Clin Nutr 2007; 85(4): 1098-1102.

41. Lucock M, Yates Z. Folic acid - vitamin and panacea or genetic time bomb? Nat Rev Genet 2005; 6(3): 235-240.

42. Junaid MA, Kuizon S, Cardona J, Azher T, Murakami N, Pullarkat RK, Brown WT. Folic acid supplementation dysregulates gene expression in lymphoblastoid cells--implications in nutrition. Biochem Biophys Res Commun 2011; 412(4): 688-692.

43. Kelly P, McPartlin J, Goggins M, Weir DG, Scott JM. Unmetabolized folic acid in serum: acute studies in subjects consuming fortified food and supplements. Am J Clin Nutr 1997; 65(6): 17901795.

44. Assaraf YG. Molecular basis of antifolate resistance. Cancer Metastasis Rev 2007; 26(1): 153-181. 